\title{
Evaluation of Different Fungal and Bacterial Antagonists against Fusarium Wilt of Eggplant caused by Fusarium oxysporum f. sp. melongenae
}

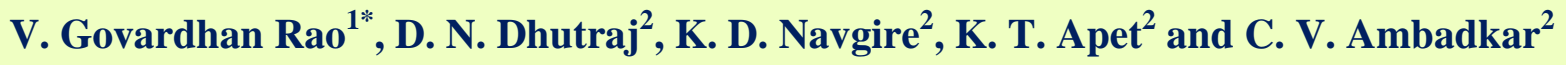 \\ ${ }^{1}$ Banana Research Station, Dr.YSR Horticultural University, Venkatampalli, \\ APCARL-Campus, Pulivendula, Y.S.R. Kadapa District-516 390 (AP), India \\ ${ }^{2}$ College of Agriculture, Vasanthrao Naik Marathwada Krishi Vidya Peeth (VNMKV), \\ Parbhani-431402, Maharastra, India \\ *Corresponding author
}

\section{A B S T R A C T}

\section{Keywords}

Eggplant, Fusarium wilt, Biological control, Duel and pot culture

\section{Article Info}

Accepted:

28 August 2020

Available Online:

10 September 2020
Eggplant is one of the important economic vegetable crops which are attacked by several serious diseases such as wilt. Fusarium oxysporum f. sp. melongenae was isolated from a naturally occurring epidemic of wilt in eggplant plants grown in Maharashtra. Among six bioagents evaluated in vitro against $F$. oxysporum f.sp melangene, Trichoderma harzianum was found effective with maximum inhibition of mycelial growth of the pathogen $(67.77$ $\%$ ),followed by Aspergillus nizer (65.92\%). While, B.subtilis found to be most effective $(45.55 \%)$ among antagonistic bacteria under duel culture study. Similar efficacy observed during pot culture study. Trichoderma harzianum was found most effective with least preemergence seedling mortality $(7.66 \%)$ with 84.89 per cent reduction over control. The second and third best antagonists found were A. nizer and T. hamatum which recorded preemergence seedling mortality of 11.33 and 13.66 with 77.51 and 64.23 per cent reduction over control respectively.

\section{Introduction}

Brinjal is commonly known as Eggplant (Solanum melongena Linn.) It is belongs to the family Solanaceae. Brinjal is a widely grown vegetable crop in Asian countries, probably a native of South Asia. Brinjal is growing throughout the India covering an area of 668.72 thousand ha with production of 123.99 thousand tonnes and productivity of $18.53 \mathrm{M}$. tonnes / ha. In Maharashtra, the area, production and productivity of Brinjal were 221.40 thousand ha, 433.28 thousand tonnes and 19.68 M. tones / ha, respectively during 2016-17 (Horticultural statistics at a glance, 2017).
Fusarium species are the most important plant pathogens in the world and highly variable because of their genetic makeup and changes in environment in which they grow causing morphological changes (Nelson, 1983). Fusarium wilt of eggplant caused by Fusarium oxysporum f. sp. melongenae is an economically important soil borne disease limiting eggplant production worldwide. This pathogen was initially reported in Japan (Matuo and Ishigami, 1958), and next in China (Zhuang et al., 2005).

It is extremely difficult to control soil-borne fungi through conventional strategies such as 
the use of synthetic fungicides, etc. Since their spores are able to survive for many years in the soil, biological control strategies for this pathogen should, therefore, be carefully selected and handled in an eco-friendly way instead of using chemical fungicides.

The application of microorganisms as biocontrol agents is important, since they may increase beneficial microbial activity which extends for a long period of time. Trichoderma spp. are considered as potential biocontrol and growth promoting agents for many crop plants (Verma et al., 2007; Savazzini et al., 2009).

The competition with pathogens, parasitism and the production of antifungal compounds are the most important mechanisms in biocontrol activity (Verma et al., 2007; Savazzini et al., 2009). Trichoderma populations can be established relatively easily in different types of soil and can continue to persist at detectable levels for months.

In the above context, the present study was undertaken to isolate the Fusarium wilt pathogen from the economically important eggplant crop and evaluate the potential of an isolated indigenous strain of fungal and bacterial antagonists under in vitro and screen house conditions.

\section{Materials and Methods}

\section{Biocontrol agents}

Pure cultures and talc based formulations of biocontrol agents viz., Trichoderma viride, $T$. harzianum, T. hamatum, T. longibrachiatum, T. virens, T. koningii, Aspergillus niger, Pseudomonas fluorescens, Pseudomonas striata and Bacillus subtilis were obtained from the Spawn Production-cum-Biocontrol Laboratory, Department of Plant Pathology, College of Agriculture, VNMKV, Parbhani. These cultures were maintained and multiplied on appropriate culture media and used for present studies.

\section{In vitro evaluation of bioagents (Duel culture)}

Using dual culture technique (Dennis and Webster, 1971), seven fungal and three bacterial bioagents were evaluated in vitro against FOM. In this study seven days old bioagents cultures and test pathogen (FOM) culture were used. $5 \mathrm{~mm}$ culture discs of the test pathogen and test bioagents were cut with sterilized cork borer and placed on autoclaved and solidified PDA medium in Petri plates, exactly opposite to each other. PDA plates inoculated only with the test pathogen were maintained as untreated control. Three replications were incubated at $27 \pm 2{ }^{\circ} \mathrm{C}$.

\section{Experimental details}

\begin{tabular}{|c|c|}
\hline Design & C.R.D. (Completely Randomized Design) \\
\hline Replications & Three \\
\hline Treatments & Eleven \\
\hline
\end{tabular}

Bioagent Treatments

\begin{tabular}{|c|l|c|l|}
\hline Tr.No. & \multicolumn{1}{|c|}{ Treatments } & Tr. No. & \multicolumn{1}{c|}{ Treatments } \\
\hline $\mathrm{T}_{1}$ & Trichoderma viride & $\mathrm{T}_{6}$ & T. koningii \\
\hline $\mathrm{T}_{2}$ & T. harzianum & $\mathrm{T}_{7}$ & Aspergillus niger \\
\hline $\mathrm{T}_{3}$ & T. hamatum & $\mathrm{T}_{8}$ & Pseudomonas fluorescens \\
\hline $\mathrm{T}_{4}$ & T. longibrachiatum & $\mathrm{T}_{9}$ & Pseudomonas striata \\
\hline $\mathrm{T}_{5}$ & T. (Gliocladium) virens & $\mathrm{T}_{10}$ & Bacillus subtilis \\
\hline & & $\mathrm{T}_{11}$ & Control (Untreated) \\
\hline
\end{tabular}


Observations on linear mycelial growth of the test pathogen and test bioagent were recorded at a 24-hour interval and continued until untreated control plates were fully covered with mycelial growth of the test pathogen. By applying the following equation (Arora and Upaddhyay, 1978), per cent inhibition of the test pathogen with the test bioagent was determined over untreated territory.

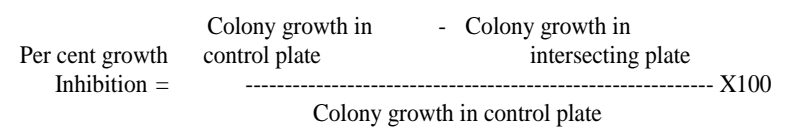

\section{In vitro evaluation of bioagents (Pot culture)}

Brinjal seeds were soaked in double the volume of sterile distilled water containing the talc based formulation (10 g kg-1 of seed). After $24 \mathrm{~h}$, the suspension was drained off and the seeds were dried under shade for 30 min and used for sowing (Nandakumar et al., 2001). A pure culture of test pathogen was introduced into a Sand-Maize (19:1) medium and incubated for 15 days at room temperature for multiplication. The potting soil (red soil: sand: cow dung manure, 1:1:1 w: w: w) was incorporated with the fungus, and seeds of brinjal were surface-sterilized with $0.1 \%$ mercuric chloride for 30 seconds, rinsed three times with sterile distilled water and sown at 10 seeds per pot. Five grams of talc based formulation per $\mathrm{kg}$ of soil was added 30 days after sowing.

Observations on Pre-emergency mortality (PREM) after a week of sowing and postemergency mortality (POEM) / wilting at 90 days after sowing were recorded. Percent of pre-emergency mortality (PREM) and postemergency mortality (POEM)/wilting were calculated using the following formulae:

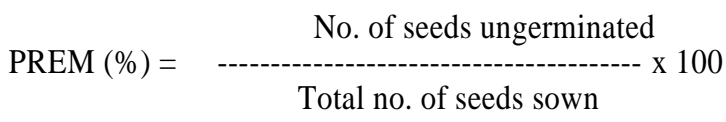

$$
\operatorname{POEM}(\%)=\quad \begin{aligned}
& \text { No. of seedlings died } \\
& ----------- \\
& \text { Total no. of seedlings }
\end{aligned}
$$

\section{Results and Discussion}

\section{In vitro evaluation of bioagents (Duel culture)}

The results obtained on mycelial growth and inhibition of Fusarium oxysporum f.sp. melongenae with seven fungal and three bacterial antagonists were presented in Table 1. All the bioagents exhibited fungistatic / antifungal activity against Fusarium oxysporum f.sp. melongenae. and significantly inhibited its growth, over untreated control (Fig. 1 and Plate I).

Of the bioagents / antagonists tested, Trichoderma harzianum was found most effective with least linear mycelial growth $(29.00 \mathrm{~mm})$. The second and third best antagonists found were A.nizer. and $T$. hamatum, which recorded least mycelial growth of $30.67 \mathrm{~mm}$ and $34.00 \mathrm{~mm}$, respectively. These were followed by T.longibrachiatum (43.67), Bacillus subtilis (49.00), T.koningi (54.00), Pseudomonas striata (63.33), Pseudomonas fluorescens (65.33), T. viride (67.67) and $T$. virens (84.00). All treatments were significantly superior over untreated control (Table 1, Fig. 1 and Plate I).

Out of the ten antagonists tested, Trichoderma harzianum was found most effective with highest mycelial growth inhibition $(67.77 \%)$ of the test pathogen. The second and third inhibitor antagonists found were $A$. nizer and T. hamatum with and inhibition of 65.92 and 62.22 per cent, respectively. These were followed by $T$. longibrachiatum (51.48), Bacillus subtilis (45.55), T. koningi (40.00), Pseudomonas.striata (29.63), Pseudomonas fluorescens (27.40), T. viride (24.81) and $T$. virens (6.66).Thus, in order of merit the 
bioagents viz., Trichoderma harzianum, A.nizer. T. hamatum T. longibrachiatum. Bacillus subtilis, T.koningi, Pseudomonas striata, Pseudomonas fluorescens, T. viride and $T$. virens were found most potential antagonists against Fusarium oxysporum f.sp. melongenae.

These results were in agreement with Bashar and Chakma (2014) who demonstrated that the maximum inhibition (70.58\%) of the pathogen was recorded with $T$. harzianum, followed by $T$. viride. Rini and Sulochana (2006) as well as Kapoor (2008) reported that Trichoderma spp., i.e., T. harzianum was more effective antagonist than $P$. fluorescens against $F$. solani and $F$. oxysporum. The present findings were in conformity with the work of Devi and Singh (2012) who found similar in vitro results, in which the inhibition of the pathogen was maximum with $T$. harzianum followed by A.nizer and very less effect of $P$. fluorescens and B.subtilis were found in inhibition of the pathogen. However, Srideepthi and Krishna (2015) reported the efficacy of $T$. viride and $T$. harzianum against Fusarium oxysporum f.sp. capsici, which showed 68.4 and 34.2 per cent of mycelial inhibition, respectively. This variation in effectiveness might be due to difference in nature, quality and quantity of the inhibitory substances produced by these antagonistic soil fungi (Kexiang et al., 2002).

Table.1 In vitro efficacy of bioagents against Fusarium oxysporum f. sp.melongenae (duel culture)

\begin{tabular}{|c|c|c|c|}
\hline Tr. No. & Treatments & Colony Dia.(mm) & Per cent growth inhibition \\
\hline $\mathbf{T}_{1}$ & Trichoderma viride & 67.67 & $\begin{array}{c}24.81 \\
(29.84)^{*}\end{array}$ \\
\hline $\mathbf{T}_{2}$ & T. harzianum & 29.00 & $\begin{array}{c}67.77 \\
(55.39)\end{array}$ \\
\hline $\mathbf{T}_{3}$ & T. hamatum & 34.00 & $\begin{array}{c}62.22 \\
(52.05)\end{array}$ \\
\hline $\mathbf{T}_{4}$ & T. virens & 84.00 & $\begin{array}{c}6.66 \\
(14.84)\end{array}$ \\
\hline $\mathbf{T}_{5}$ & T. longibrachiatum & 43.67 & $\begin{array}{c}51.48 \\
(45.83)\end{array}$ \\
\hline $\mathbf{T}_{6}$ & Aspergillus niger & 30.67 & $\begin{array}{c}65.92 \\
(54.26)\end{array}$ \\
\hline $\mathbf{T}_{7}$ & T. koningii & 54.00 & $\begin{array}{c}40.00 \\
(39.21)\end{array}$ \\
\hline $\mathbf{T}_{8}$ & Pseudomonas fluorescens & 65.33 & $\begin{array}{c}27.40 \\
(31.55)\end{array}$ \\
\hline $\mathbf{T}_{9}$ & Pseudomonas striata & 63.33 & $\begin{array}{c}29.63 \\
(32.96)\end{array}$ \\
\hline $\mathbf{T}_{10}$ & Bacillus subtilis & 49.00 & $\begin{array}{c}45.55 \\
(42.43)\end{array}$ \\
\hline $\mathbf{T}_{11}$ & Control (untreated) & 90.00 & $\begin{array}{c}0.00 \\
(0.00)\end{array}$ \\
\hline & $\mathrm{SE}(\mathbf{m}) \pm$ & 0.69 & 0.59 \\
\hline & C.D $(P=0.01)$ & 2.03 & 1.75 \\
\hline
\end{tabular}

Dia: Diameter *Figures in parentheses are angular transformed values 
Table.2 In vitro efficacy of bio control agents against Fusarium oxysporum f.sp. melongenae in pot culture

\begin{tabular}{|c|c|c|c|c|c|}
\hline $\begin{array}{l}\text { Tr. } \\
\text { No. }\end{array}$ & Treatments & PREM & $\begin{array}{l}\text { Per cent reduction } \\
\text { over control }\end{array}$ & $\begin{array}{l}\text { POEM at } \\
100 \text { days }\end{array}$ & $\begin{array}{l}\text { Per cent reduction } \\
\text { over control }\end{array}$ \\
\hline $\mathbf{T}_{1}$ & Trichoderma viride & $\begin{array}{c}26.66 \\
(30.98)\end{array}$ & 46.74 & $48.16(43.92)$ & 28.82 \\
\hline $\mathbf{T}_{2}$ & T. harzianum & $\begin{array}{c}7.66 \\
(15.92)\end{array}$ & 84.89 & $\begin{array}{l}20.00 \\
(26.44)\end{array}$ & 70.44 \\
\hline $\mathbf{T}_{3}$ & T. hamatum & $13.66(25.04)$ & 64.23 & $35.83(34.92)$ & 47.04 \\
\hline $\mathbf{T}_{4}$ & T. virens & $24.66(29.76)$ & 50.86 & $50.52(45.28)$ & 25.34 \\
\hline $\mathbf{T}_{5}$ & T. longibrachiatum & $18.00(21.59)$ & 72.79 & $\begin{array}{c}36.66 \\
(37.21)\end{array}$ & 45.81 \\
\hline $\mathbf{T}_{6}$ & Aspergillus niger & $\begin{array}{c}11.33 \\
(19.63)\end{array}$ & 77.51 & $33.23(36.73)$ & 50.89 \\
\hline $\mathbf{T}_{7}$ & T. koningii & $\begin{array}{c}21.33 \\
(27.43)\end{array}$ & 57.59 & $\begin{array}{c}44.11 \\
(41.57)\end{array}$ & 34.81 \\
\hline $\mathbf{T}_{8}$ & Pseudomonas fluorescens & $23.00(28.63)$ & 54.14 & $\begin{array}{c}47.14 \\
(43.33)\end{array}$ & 30.33 \\
\hline $\mathbf{T}_{9}$ & Pseudomonas striata & $23.00(28.60)$ & 54.05 & $46.00(42.66)$ & 32.02 \\
\hline $\mathbf{T}_{10}$ & Bacillus subtilis & $\begin{array}{c}20.33 \\
(26.76)\end{array}$ & 59.54 & $38.66(38.40)$ & 42.86 \\
\hline $\mathbf{T}_{11}$ & Control (untreated) & $\begin{array}{c}50.33 \\
(45.17)\end{array}$ & 0.00 & $67.66(55.33)$ & 0.00 \\
\hline & SE(m) \pm & 1.33 & 2.35 & 2.57 & 4.22 \\
\hline & C.D. $(P=0.01)$ & 3.93 & 6.94 & 7.6 & 12.46 \\
\hline
\end{tabular}

*Figures in the parenthesis are angular transformed values

Fig.1 In vitro evaluation of bioagents against mycelial growth and sporulation of Fusarium oxysporum f. sp.melongenae

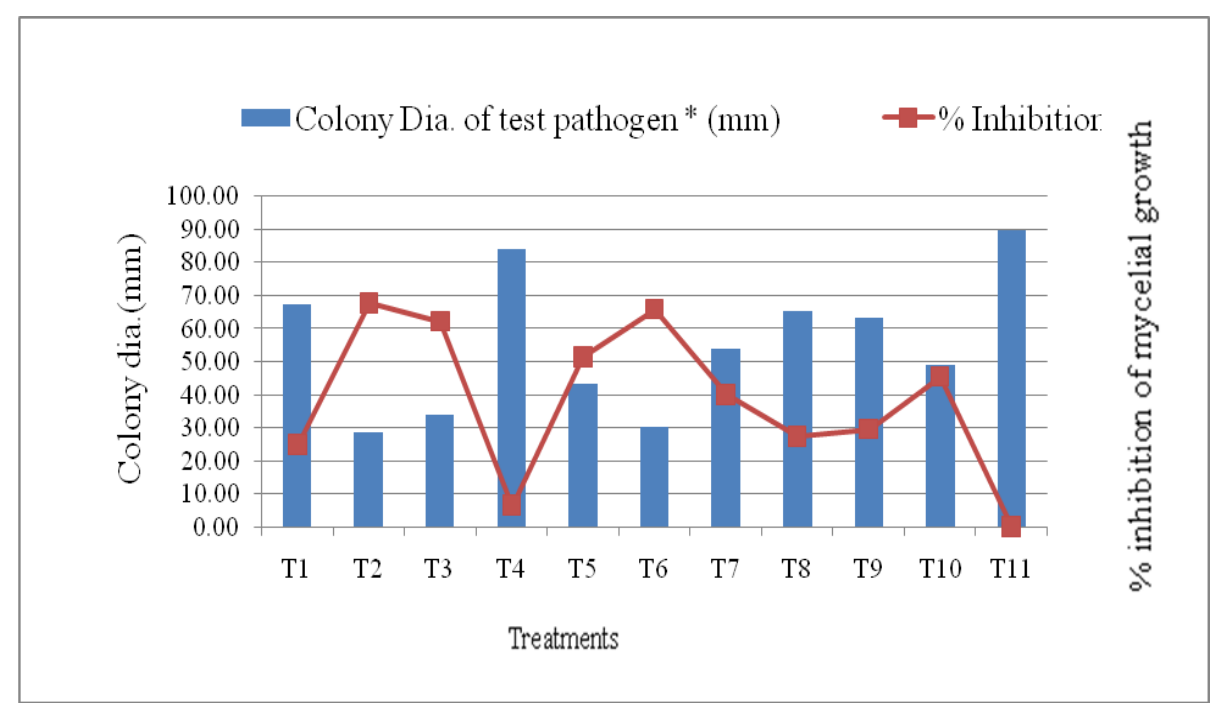


Fig.2 In vitro efficacy of bioagents against Fusarium oxysporum f.sp.melongenae in pot culture

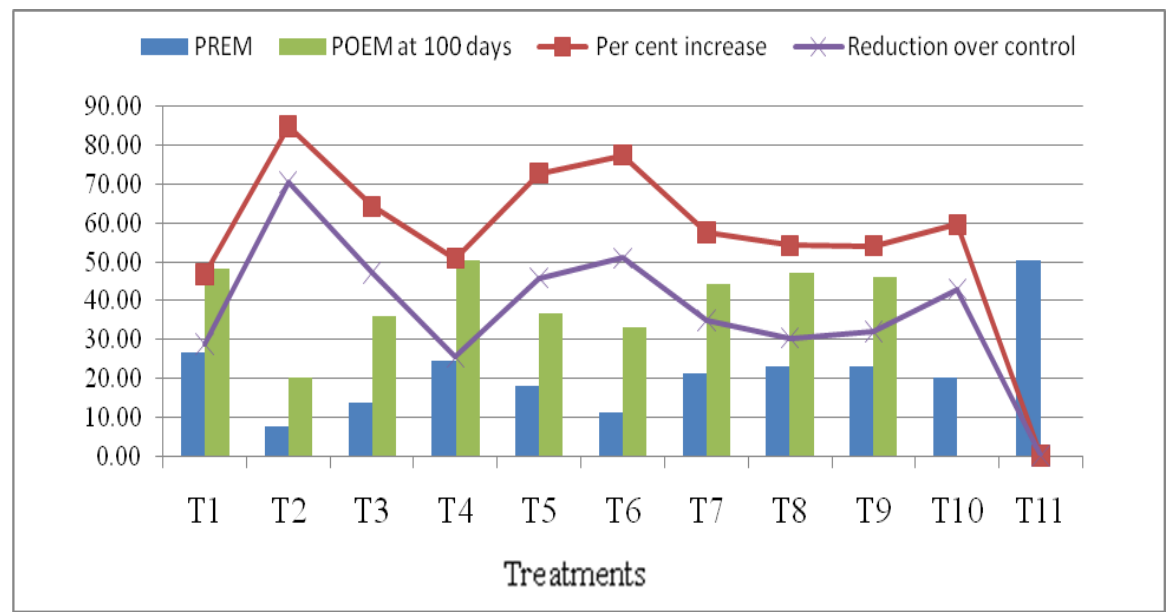

Species of Trichoderma viz., T. harzianum (T2) and A.nizer (T6) showed higher mycelial inhibition of the test fungus as compared to the bacterial antagonists (T8, T9 \& T10). This can be attributed to the higher competitive ability of the Trichoderma species as these antagonists adopt different mechanisms viz., competition, lysis, antibiosis, siderophore production and hyperparasitism. In comparison to $T$. viride, the $T$. harzianum showed faster growth with higher inhibition of the fungus by producing extracellular lytic enzymes, which arrested the growth of $F$. oxysporum. High antagonistic activity of the Trichoderma species observed against the test fungus might be due to their fast growing nature, rapid sporulation and toxic metabolite producing capacity. Similar findings of higher antagonistic effect of Trichoderma species against Fusarium species recorded previously by Vidyasekaran (1999) and Barakat et al., (2013).

\section{In vitro efficacy of bioagents (Pot culture)}

The results obtained on efficacy of ten bio agents against pre-emergence mortality and post emergence mortality of eggplant seedlings caused by Fusarium oxysporum f.sp. melongenae are presented in Table 2.
Results revealed that all the bioagents exhibited fungistatic / antifungal activity against Fusarium oxysporum f.sp. melongenae and significantly inhibited its pre-emergence seedling mortality over untreated control (Fig.2 and Plate II).

Among the bioagents / antagonists tested, Trichoderma harzianum was found most effective with least pre-emergence seedling mortality $(7.66 \%)$ with 84.89 per cent reduction over control.

The second and third best antagonists found were $A$. nizer. and $T$. hamatum which recorded pre-emergence seedling mortality of 11.33 and 13.66 with 77.51 and 64.23 per cent reduction over control respectively. These were followed by, T. longibrachiatum (18.00), T. koningi (21.33), T. (Gliocladium) virens (24.66), Bacillus subtilis (20.33), Pseudomonas fluorescens (23.00), Pseudomonas striata (23.66) and T. viride (26.66) with $72.79,59.54,57.59,54.14$, $54.05,50.86$ and 46.74 per cent reduction over control respectively. All treatments were significantly superior over untreated control.

Out of the ten antagonists tested, Trichoderma harzianum was found most effective with lowest Post-emergence seedling mortality 
(20.00\%) caused by the test pathogen with 70.44 per cent reduction over control.

The second and third inhibitor antagonists found were A.nizer and T. hamatum with least post-emergence seedling mortality of 33.23 .00 and 35.83 per cent with 50.89 and 47.04 per cent reduction over control respectively. They were followed by $T$. longibrachiatum (36.66\%), Bacillus subtilis (38.66\%), T. koningi (44.11\%), Pseudomonas striata (46.00\%), Pseudomonas fluorescens (47.14\%), T. viride (48.16\%) and T. virens $(50.52 \%)$. However, in view of per cent reduction over control performed by bioagents against Post-emergence seedling mortality were Trichoderma harzianum (70.44\%), A.nizer (50.89\%) T. longibrachiatum (45.81\%), Bacillus subtilis (42.86\%), T. koningi (34.81\%), Pseudomonas.striata (32.02\%), Pseudomonas fluorescens $(30.33 \%)$, T. viride $(28.82 \%)$ and T. virens $(25.34 \%)$.

The variation among the different isolates of Trichoderma species may be due to their genetic makeup for the antagonistic activity, production of virulence factor such as metabolites, trichodene (Lorito et al., 1994). Moreover, a variety of extracellular lytic enzymes such as high chitinase and $\beta-(1,3)$ glucanase reported to be produced by $T$. harzianum, and there might be relationship between the production of these enzymes and the ability to inhibit the pathogen. In order to survive and compete, Trichoderma produces a wide variety of toxic and antibiotic metabolites that are active against large number of plant pathogens, such as trichodermin, trichodermol, harzianum-A, harzianolide, T39-butenolide, terpenes and polypeptides and extracellular hydrolytic enzymes (Thrane et al., 2000), which were involved in the inhibition, competition, and mycoparasitism of Fusarium species.
The B. subtilis, a bacterial antagonists produces a wide range of antifungal compounds, such as subtilin, TasA, subtilosin, bacilysin, mycobacillin and some enzymes, which can degrade fungal cell wall (Berg et al., 2001). Antagonistic activity of three isolates of Trichoderma species against $F$. solani and $F$. oxysporum f.sp. lycopersici due to parasitism, competition and antibiosis, coiling and penetration of antagonistic hyphae of $T$. virens and $T$. harzianum around the hyphae of $F$. solani and their lysis, production of organic metabolites and induction of plant defense system (Thangavelu and Musataffa, 2010). In addition, some antagonistic mechanisms of these Bacillus species involves in the competition for nutrients and space, the induction of plant resistance, increased activities of polyphenol oxidase (PPO) and peroxidase (POD), whereas, $P$. fluorescens produce an array of antifungal metabolites like siderophores and different antibiotics like phenazine-1 carboxylic acid, and 2,4-diacetyl-phloroglucinol (2,4-DAPG) preventing further advancement of the fungus by inducing severe cell disturbances in pathogenic fungi (Beckman et al., 1982). T. harzianum is a non pathogenic fungus that captures the root zone for its profuse growth and competes with the pathogenic microorganisms for space and nutrition. Sometimes T. harzianum secretes some toxins and enzymes injurious to pathogenic organisms. Moreover, it can directly parasitize other soil borne pathogens. This myco-parasitism might be the reason of controlling wilt pathogens (Faruq et al., 2014).

In conclusions among six bioagents evaluated in vitro against $F$. oxysporum f.sp melangene, Trichoderma harzianum was found effective with maximum inhibition of mycelial growth of the pathogen (67.77\%),followed by Aspergillus nizer (65.92\%). While, B.subtilis found to be most effective $(45.55 \%)$ among 
antagonistic bacteria under duel culture study. Similar efficacy observed during pot culture study. Trichoderma harzianum was found most effective with least pre-emergence seedling mortality (7.66 \%) with 84.89 per cent reduction over control.

\section{References}

Arora, D. K. and Upadhyay, R. K. (1978). Effect of fungal staling growth substances on colony interaction. Plant and Soil. 49: 685-690.

Barakat, F.M., Abou- Zeid, N.M.A. and El- Gammal, Y.H.E. (2013). Effect of volatile and nonvolatile compounds of Trichoderma spp. on Botrytis fabae the causative agent of faba bean chocolate spot. Journal of Agricultural Research. 1 (3): 42-50.

Bashar, M.A. and Chakma, M. (2014). In vitro control of Fusarium solani and $F$. oxysporum the causative agent of brinjal wilt.Dhaka University Journal of Biological Sciences. 23(1): 53-60.

Beckman, C.H., Mueller, W.C., Tessier, B.J. and Harrisson, N.A. (1982). Recognition and callose deposition in response to vascular infection in Fusarium wilt-resistant or susceptible tomato plants. Physiological Plant Pathology. 20: 1-10.

Berg, G., Fritze, A., Roskot, N. and Smalla, K. (2001). Evaluation of potential biocontrol rhizobacteria from different host plants of Verticillium dahliae Kleb. Journal of Applied Microbiology.91: 963- 971.

Dennis, K. L. and Webster, J. (1971). Antagonistic properties of species group of Trichoderma and hyphal interaction. Trans. British Mycol. Soc. 57: 363-396.

Devi, T.N. and Singh, M.S. (2012). Evaluation of suitable fungicide for integration with Trichoderma isolates for the control of tomato wilt. Journal of
Mycopathological Research. 50: 223228.

Faruq, A.N. Islam, M. T. Bhuiyan, M. Z. R. Mamun-ur-Rashid, Md. Amin, M. R. and Sanzida Hoque. (2014). Efficacy of soil application with Trichoderma harzianum $\mathrm{T}_{22}$ and some selected soil amendments on Fusarium wilt of eggplant (Solanum melongena L.). App. Sci. Report. 8 (2): 69-74.

Kapoor, A.S. (2008). Biocontrol potential of Trichoderma spp. against important soil-borne diseases of vegetable crops. Indian Phyto pathology.61: 492-498.

Kexiang, G., Xiaoguang, L., Youghong, L., Tianbo, Z. and Shuliang, W. (2002). Potential of Trichoderma harzianum and $T$. atroviride to control Botryosphaeria berengeriana f.sp. piricola, the cause of apple ring rot. Phytopathology.150: 271- 276.

Lorito, M., Peterbauer, C., Hayes, C.K. and Harman, G.E. (1994). Synergistic interaction between fungal cell wall degrading enzymes and different antifungal compounds enhances inhibition of spore germination. Microbiology. 140(3): 623-629.

Matuo, T. and Ishigami, K. (1958). On the wilt of Solanum melongena $\mathrm{L}$. and its causal fungus Fusarium oxysporum f. melongenae $n$. f. Jpn J Phytopathol. 23:189 -192.

Nandakumar R, Babu S, Viswanathan R, Sheela J, Raguchander T, Samiyappan R. 2001. A new bio-formulation containing plant growth promoting rhizobacterial mixture for the management of sheath blight and enhanced grain yield in rice. Biocontrol., 46: 493-510.

Nelson P.E., T.A. Toussoun and W.F.U Marsas (1983). Fusarium species. An illustrated Manual for Identification, The Pennsylvania state univ. Press. pp.193. 
Rini,C.R. and Sulochana K.K. (2006). Biocontrol of Fusarium solani in chilli by Trichoderma spp. and fluorescent Pseudomonads. Department of Plant Biotechnology, Mar Athanasios College for Advanced Studies, Tiruvalla. Journal of Tropical Agricultur.44: 7982.

Savazzini F, Longa CMO, Pertot I (2009). Impact of the biocontrol agent Trichoderma atroviride $\mathrm{SC1}$ on soil microbial communities of a vineyard in northern mycoparasite antagonism by Trichoderma harzianum, J. Bacteriol. 178:6382-6385.

Srideepthi, R. and Krishna, M.S.R. (2015). Antimycotic effect of Trichoderma species on Fusarium oxysporum f.sp. capsici inciting vascular wilt in chilli. In: New Horizons in Biotechnology. pp. 29-31.

Thangavelu, R. and Mustaffa, M.M. (2010). A potential isolate of Trichoderma viride NRCB1and its mass production for the effective management of Fusarium wilt disease in banana. Tree and Forestry Science and Biotechnology. 4(2): 76-84.
Thrane, C., Jensen, D.F. and Tronsmo, A. (2000). Substrate colonization, strain competition, enzyme production in vitro, and biocontrol of Pythium ultimum by Trichoderma spp. isolates P1 and T3. European Journal of Plant Pathology. 106(3): 215-225.

Verma M, Brar SK, Tyagi RD, Sahai V, Prévost D, Valéro JR, Surampalli RY (2007). Bench-scale fermentation of Trichoderma viride on wastewater sludge: rheology, lytic enzymes and biocontrol activity. Enzyme Microb. Technol. 41:764-771.

Vidyasekaran, P. (1999). Biotechnological approaches to suppress seed to plant transmission of seed borne pathogens. In: National Symposium on Seed Science and Technology 5- $7^{\text {th }}$ August, University of Mysore, Manasagangotri, Mysore and India.pp.41.

Zhuang, W.Y., Guo, L., Guo, S.Y., Guo, Y.L., Mao, X.L., Sun, S.X., Wei, S.X., Wen, H.A., Yu, Z.H., Zhang, X.Q. and Zhuang, J.Y. (2005). Fungi of north western China. Mycotaxon, Ithaca, NY.

\section{How to cite this article:}

Govardhan Rao, V., D. N. Dhutraj, K. D. Navgire, K. T. Apet and Ambadkar, C. V. 2020. Evaluation of Different Fungal and Bacterial Antagonists against Fusarium Wilt of Eggplant caused by Fusarium oxysporum f. sp. melongenae. Int.J.Curr.Microbiol.App.Sci. 9(09): 36103618. doi: https://doi.org/10.20546/ijcmas.2020.909.446 